\title{
Cohering Small Group Communication with Introduction to Engineering and its Impact on Team Dynamics
}

\section{Dr. Haolin Zhu, Arizona State University}

Dr. Haolin Zhu earned her BEng in Engineering Mechanics from Shanghai Jiao Tong University and her $\mathrm{Ph} . \mathrm{D}$. in Theoretical and Applied Mechanics from Cornell University, with a focus on computational solid mechanics. After receiving her Ph.D., Dr. Zhu joined Arizona State University as a full time Lecturer and became part of the freshman engineering education team in the Ira A. Fulton Schools of Engineering. She currently holds the title of Senior Lecturer and is the recipient of the Fulton Outstanding Lecturer Award. She focuses on designing the curriculum and teaching in the freshman engineering program. She is also involved in the NAE Grand Challenge Scholars Program, the ASU ProMod project, the Engineering Projects in Community Service program, the Engineering Futures program, the Global Freshman Academy, and the ASU Kern Project. Dr. Zhu also designs and teaches courses in mechanical engineering at ASU, including Mechanics of Materials, Mechanical Design, Mechanism Analysis and Design, Finite Element Analysis, etc. She was part of a team that designed a largely team and activity based online Introduction to Engineering course, as well as a team that developed a unique MOOC introduction to engineering course for the Global Freshman Academy. Her Ph.D. research focuses on multi-scale multiphase modeling and numerical analysis of coupled large viscoelastic deformation and fluid transport in swelling porous materials, but she is currently interested in various topics in the field of engineering education, such as innovative teaching pedagogies for increased retention and student motivation; innovations in non-traditional delivery methods, incorporation of the Entrepreneurial Mindset in the engineering curriculum and its impact.

\section{Dr. David Jacob Taylor, Arizona State University Mr. Ian Derk}

Mr. Ian Derk is an instructor in the College of Integrative Sciences and Arts and PhD student in communication at the Hugh Downs School of Human Communication. He studies digital rhetoric, social networks, and educational technology. He works with hybrid class, project-based learning, and inter/transdisciplinary collaborations as part of various projects at Arizona State University. 


\title{
Cohering Small Group Communication with Introduction to Engineering and its Impact on Team Dynamics
}

\begin{abstract}
This paper will describe the impact of cohering two first year courses, Introduction to Engineering and Small Group Communication on team dynamics. One of the important skills for successful engineering students is their ability to work effectively in a team environment. There are many opportunities for students to participate in team-based work in various courses and capstone projects to help them practice teamwork skills. However, in many cases, students are on their own to make their teams work and these team-based activities do not necessarily allow students to develop effective teamwork abilities. At Arizona State University, two cohorts of first year engineering students took Introduction to Engineering and Small Group Communication together during Fall 2018 semester with cohered schedule, content, and assignments, around a small design challenge and a large design project.
\end{abstract}

The impact of this model on team dynamics in the design projects was assessed using the CARE model and assessment tool developed by the Individual and Team Performance Lab at University of Calgary. This assessment tool contains 81 Likert Scale questions about Team Dynamics covering the following areas: strategy formulation \& planning; role clarity; cooperative conflict management; team monitoring \& backup; goal progression; coordination; contribution equity; healthy, fact-driven conflict; lack of personal conflict; trust; constructive controversy; exploitative learning; and exploratory learning. The experimental group consisted of two sections of the cohered courses whereas the control group involved students enrolled in four sections of the traditional Introduction to Engineering course during the same semester. This assessment tool was given to both groups three times during the semester. Overall the experimental group outperformed the control group for the majority of the questions in all three evaluations. Less personal conflict was found in the control group from the first evaluation where differences in results between the two groups were of statistical significance. Other statistically significant differences with better performance from the experimental group were found in results from areas of healthy, fact-driven conflict (first evaluation); coordination (final evaluation); and contribution equity (final evaluation).

\section{Introduction}

Teamwork has long been recognized as an essential skill for engineering graduates to be successful in today's workplace $[1,2]$. It is very common for engineering programs to use experiential learning in the form of team projects in various courses ranging from the introductory engineering courses to capstone courses to help students develop this important skill [3-10]. Though these team based projects do provide students with opportunities to gain 
teamwork experiences, it does not necessarily mean that students will develop effective teamwork skills from these team project experiences. In many cases, students are left on their own to make their teams work, as little formal training is provided to students due to various restrictions/constraints. Some examples may include: limited time is available in the course schedule for in-depth discussions about teamwork skills, and engineering instructors may not be aware of the fundamental research and theories behind developing teamwork skills, etc. [11, 12]. To address this problem, at Arizona State University, two cohorts of first year engineering students took Introduction to Engineering and Small Group Communication together during the Fall 2018 semester with the courses having cohered schedules, content, and assignments, all centered around two team-based projects. The Introduction to Engineering course focuses on the engineering design process; opportunity identification; problem definition; design criteria; imagining possible solutions; decision making; descriptive and predictive modeling; project management; technical communication; and various tools, skills, and technical concepts that are relevant for the projects. The Small Group Communication course focuses on developing skills towards working in task-oriented groups; engaging in effective role performance; decreasing communication apprehension in small group settings; problem-solving and decision-making in small group settings; developing conflict management skills; managing and planning tasks; etc. Students apply these skills in their Introduction to Engineering team projects.

Students' teamwork skills are often measured by the effectiveness of their teams, which focuses on various factors that affect team outcomes [13]. Various team effectiveness models exist [1422] that depict characteristics of team effectiveness. One such pedagogical team effectiveness model was developed by the Individual and Team Performance Lab at the University of Calgary [11] called the team CARE model. According to this model, there are four key teamwork skills: communicate, adapt, relate, and educate. Out of these four dimensions, 'communicate' involves formulation of the team's strategy of achieving their goals based on the team's strengths and weaknesses; clear expectations and roles of each member; and team's ability to manage and resolve conflicts. 'Adapt' encompasses the team's ability to coordinate each other's efforts in order to optimize time and efficiency; monitor team's progress; and adjust and support each other when problems occur. The third dimension 'relate' refers to team members' relationships and interactions, and important characteristics include trust, interdependence, equal and fair share of teamwork, and lack of personal conflict. Finally, 'educate' in the model means team's motivation and willingness to acquire new knowledge in order to improve the team's outcomes [11]. This developmental tool can be used to assess team dynamics and provide specific information about the team's effectiveness [23].

This work aims to measure whether the intervention of cohering the first year engineering course with the Small Group Communication course has led to better team dynamics in the team projects, using the team CARE model. Teams in sections that received this intervention (experimental group) and sections that did not (control group) were assessed three times 
throughout the semester using the team CARE assessment tool [23], which contains 81 Likertscale questions that focus on the four dimensions of teamwork skills discussed above, as well as team potency and satisfaction. This team effectiveness model and assessment tool was chosen for this study due to its ease of integration into the course and the quality feedback reports generated for students to gauge their performance. In this paper, quantitative results from both groups will be compared and discussed.

\section{Context}

At Arizona State University, the first year Introduction to Engineering course has seen major transformations over the past few years and one important element that is incorporated in all sections is team based hands-on design projects done in a makerspace. In this course, teams are usually formed at the beginning of the semester and students stay in the same team for the entire semester. Team contracts and peer evaluations are often used to help prevent common team issues and evaluate individual performance in the team. However, the level of team performance often varies in each section. Students' motivation and their feelings about teamwork can also vary based on their team experiences. During the fall 2018 semester, two sections of the Introduction to Engineering course taught by the authors were cohered with the Small Group Communication course, which means the same students were enrolled in both courses and these two courses were connected to each other in multiple ways. For example, both courses utilized the same team-based projects throughout the semester and students developed skills from both courses which were then applied in the projects; both courses had cohered schedules around these projects; and there were cohered assignments between the two courses that each required only one submission but students received credit in both courses.

The Introduction to Engineering course is a 2-credit course that meets twice each week for a 50minute lecture and a 3-hour lab, and the Small Group Communication is a hybrid course with one class meeting each week. During the Fall 2018 semester, students worked in teams on a small design challenge at the beginning of the semester and then a large design project for the rest of the semester. Students self-formed teams of 3 or 4 , with students choosing their initial team based on who they sat with on the first day of class. Self-formed teams were found to be preferential in the course as previous attempts to use instructor formed teams resulted in negative feedback from the students. The majority of students taking the course are freshmen and members of the self-formed teams rarely have pre-existing relationships outside of the course. Students remained in this initial team for the duration of the small design challenge. Following the completion of the small design challenge, students were given the option to switch membership to a different team. Team memberships were held constant for the duration of the large design project. Of the 53 teams in both groups, only 3 teams had membership changes between the small and large design projects. Experience with the course has suggested that giving students more agency in their team selection has resulted in more ownership in the team's 
success/failure as reflected in student evaluations. Since teams were formed in the same way in both groups, team formation does not play a role in the differences found in the results between the groups that will be discussed in later sections.

\section{Research Method}

The goal of this research is to understand if the intervention of cohering Introduction to Engineering and Small Group Communication has resulted in better team dynamics. The experimental group involved in this study includes two sections of the cohered courses with 37 and 20 students each. The control group consists of four sections of traditional Introduction to Engineering course taught by the authors in the same semester with approximately 40 students each. Out of these four control group sections, one had the same projects as the experimental group while the other three had a different small design challenge and large design project with similar objectives, lengths, and deliverables. The same team structure was implemented in both groups. The team CARE assessment tool was administered to individuals in both groups three times throughout the semester, once after the mini team design challenge, once during the middle of the large design project, and once at the end of the course [23]. Categories for the questions are listed in Table 1 below. A Likert scale of 1-5 is used for these questions, with 1 being strongly disagree and 5 being strongly agree. Besides these questions, there are also questions about team potency and team satisfaction. The complete list of questions in this assessment tool can be found in Appendix A [23]. 
Table 1. Team CARE assessment tool questions categories [23]

\begin{tabular}{|l|l|l|l|l|}
\hline $\begin{array}{l}\text { Team CARE } \\
\text { model dimension }\end{array}$ & \multicolumn{4}{|c|}{ Subcategories } \\
\hline Communicate & $\begin{array}{l}\text { Strategy } \\
\text { Formulation }\end{array}$ & Role Clarity & $\begin{array}{l}\text { Cooperative Conflict } \\
\text { Management }\end{array}$ & \\
\hline Adapt & $\begin{array}{l}\text { Team Monitoring } \\
\text { and Backup }\end{array}$ & $\begin{array}{l}\text { Emphasizing Goal } \\
\text { Progression }\end{array}$ & Coordination & \\
\hline Relate & Trust & $\begin{array}{l}\text { Healthy, Fact-Driven } \\
\text { Conflict }\end{array}$ & $\begin{array}{l}\text { Lack of Personal } \\
\text { Conflict }\end{array}$ & $\begin{array}{l}\text { Contribution } \\
\text { Equity }\end{array}$ \\
\hline Educate & $\begin{array}{l}\text { Exploratory } \\
\text { Learning }\end{array}$ & Exploitative Learning & $\begin{array}{l}\text { Constructive } \\
\text { Controversy }\end{array}$ & \\
\hline
\end{tabular}

\section{Findings}

The experimental group consisted of 15 teams and there were a total of 38 teams in the control group. Quantitative results displayed in Figure 1 show that the experimental group had a higher overall mean value for each of the three evaluations, though the differences were not found to be statistically significant ( $\mathrm{p}>0.05)$.

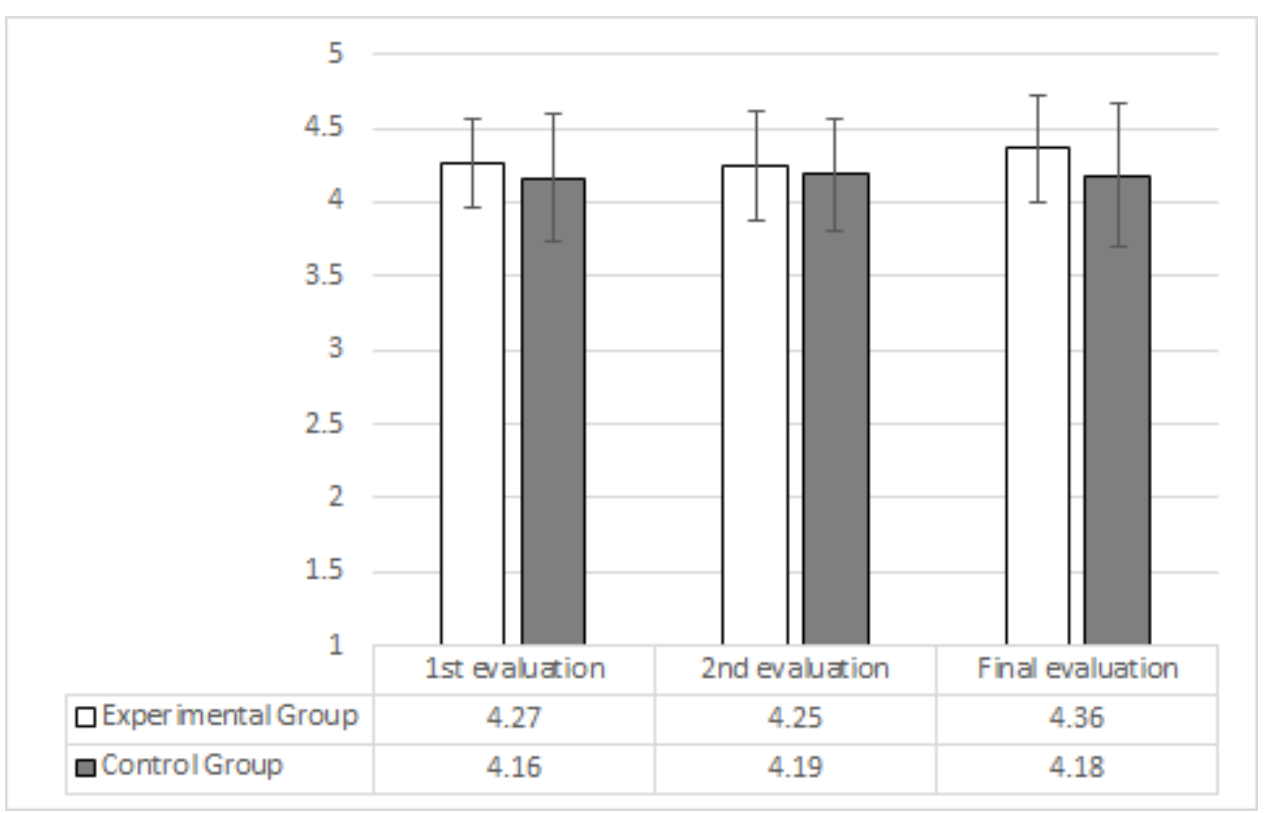

Figure 1. A comparison of overall mean values between the two groups. A Likert scale of 1-5 was used, with 1 being strongly disagree and 5 being strongly agree. 
The overall mean values for the four dimensions of the team CARE model can be found in Figure 2 for all the three evaluations. The experimental group was found to have higher mean values for 'Communicate', 'Adapt', and 'Educate' in all three evaluations. Out of these three dimensions, the greatest difference was found in the final evaluation for 'Adapt'. The control group had slightly higher mean values in the first two evaluations for the dimension 'Relate'. None of these results was of statistical significance ( $p>0.05)$, however, the following results had $\mathrm{p}$ values which were smaller than 0.10: 'Adapt' and 'Educate' in the first evaluation, and 'Adapt' and 'Relate' in the final evaluation.

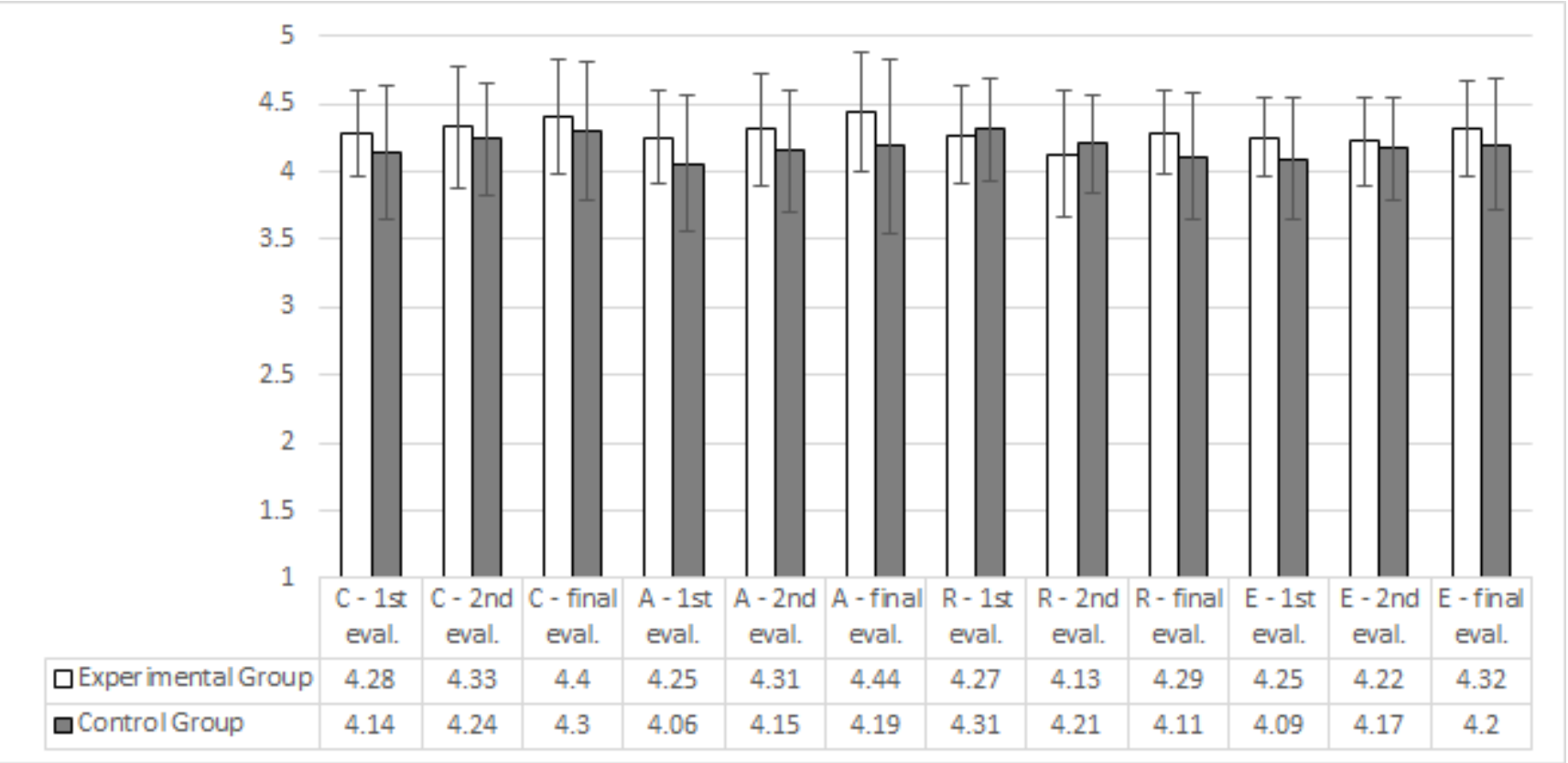

Figure 2. Overall mean values for the four dimensions of team care model (C-Care, A - Adapt, $\mathrm{R}$ - Relate, E - Educate). A Likert scale of 1-5 was used, with 1 being strongly disagree and 5 being strongly agree.

A comparison of the results between the two groups for the subcategories of each of the four dimensions of the team CARE model can be found in Table 2. The mean values for the experimental group were higher in almost all subcategories for all the three evaluations, except for only one or two subcategories in each evaluation. Statistically significant differences were found in subcategories healthy, fact-driven conflict and lack of personal conflict in the first evaluation, and in subcategories coordination and contribution equity in the final evaluation. The other subcategories for which the results are worth noting include exploitative learning in the first evaluation, goal progression in the first and final evaluations, as well as trust in the final evaluation $(\mathrm{p}<0.10)$. 
Table 2. Mean values for subcategories of team CARE model $\left(* \mathrm{p}<0.10,{ }^{* *} \mathrm{p}<0.05\right)$

\begin{tabular}{|l|l|l|l|l|l|l|l|l|l|}
\hline & \multicolumn{3}{|c|}{ First evaluation } & \multicolumn{3}{c|}{ Second evaluation } & \multicolumn{3}{c|}{ Final evaluation } \\
\hline & $\begin{array}{l}\text { Experi- } \\
\text { mental }\end{array}$ & Control & $\begin{array}{l}\text { Mean } \\
\text { Difference }\end{array}$ & $\begin{array}{l}\text { Experi- } \\
\text { mental }\end{array}$ & Control & $\begin{array}{l}\text { Mean } \\
\text { Difference }\end{array}$ & $\begin{array}{l}\text { Experi- } \\
\text { mental }\end{array}$ & Control & $\begin{array}{l}\text { Mean } \\
\text { Difference }\end{array}$ \\
\hline $\begin{array}{l}\text { Conflict } \\
\text { management }\end{array}$ & 4.42 & 4.29 & 0.13 & 4.37 & 4.33 & 0.04 & 4.46 & 4.38 & 0.08 \\
\hline Role clarity & 4.22 & 4.08 & 0.14 & 4.36 & 4.19 & 0.17 & 4.37 & 4.24 & 0.13 \\
\hline $\begin{array}{l}\text { Strategy \& } \\
\text { planning }\end{array}$ & 4.23 & 4.09 & 0.14 & 4.28 & 4.25 & 0.03 & 4.37 & 4.28 & 0.09 \\
\hline $\begin{array}{l}\text { Monitoring \& } \\
\text { backup }\end{array}$ & 4.21 & 4.04 & 0.17 & 4.31 & 4.15 & 0.16 & 4.41 & 4.21 & 0.20 \\
\hline $\begin{array}{l}\text { Goal } \\
\text { progression }\end{array}$ & $\mathbf{4 . 1 7}$ & $\mathbf{3 . 9 3}$ & $\mathbf{0 . 2 4 *}$ & 4.22 & 4.14 & 0.08 & $\mathbf{4 . 4 1}$ & $\mathbf{4 . 1 2}$ & $\mathbf{0 . 2 9 *}$ \\
\hline Coordination & 4.39 & 4.22 & 0.17 & 4.43 & 4.20 & 0.23 & $\mathbf{4 . 5 3}$ & $\mathbf{4 . 2 4}$ & $\mathbf{0 . 2 9} * *$ \\
\hline $\begin{array}{l}\text { Contribution } \\
\text { equity }\end{array}$ & 4.30 & 4.53 & -0.23 & 4.19 & 4.36 & -0.17 & $\mathbf{4 . 5 5}$ & $\mathbf{4 . 0 6}$ & $\mathbf{0 . 4 9 * *}$ \\
\hline $\begin{array}{l}\text { Healthy fact- } \\
\text { driven } \\
\text { conflict }\end{array}$ & $\mathbf{3 . 8 1}$ & $\mathbf{3 . 5 0}$ & $\mathbf{0 . 3 1 * *}$ & 3.53 & 3.38 & 0.15 & 3.31 & 3.41 & -0.10 \\
\hline $\begin{array}{l}\text { Lack of } \\
\text { personal } \\
\text { conflict }\end{array}$ & $\mathbf{4 . 4 2}$ & $\mathbf{4 . 6 7}$ & $\mathbf{- 0 . 2 5 * *}$ & 4.39 & 4.58 & -0.19 & 4.65 & 4.51 & 0.14 \\
\hline Trust & 4.45 & 4.32 & 0.13 & 4.40 & 4.23 & 0.17 & $\mathbf{4 . 4 8}$ & $\mathbf{4 . 1 9}$ & $\mathbf{0 . 2 9 *}$ \\
\hline $\begin{array}{l}\text { Constructive } \\
\text { controversy }\end{array}$ & 4.37 & 4.25 & 0.12 & 4.36 & 4.30 & 0.03 & 4.39 & 4.26 & 0.13 \\
\hline $\begin{array}{l}\text { Exploitative } \\
\text { learning }\end{array}$ & $\mathbf{4 . 1 9}$ & $\mathbf{4 . 0 4}$ & $\mathbf{0 . 1 5 *}$ & 4.14 & 4.12 & 0.02 & 4.29 & 4.21 & 0.08 \\
\hline $\begin{array}{l}\text { Explorative } \\
\text { learning }\end{array}$ & 4.19 & 3.98 & 0.21 & 4.20 & 4.12 & 0.08 & 4.33 & 4.15 & 0.18 \\
\hline
\end{tabular}


Figure 3 shows the mean differences between the two groups for questions related to team potency and team satisfaction in all three evaluations. The greatest differences were found in both categories in the final evaluation and the results for team potency had $\mathrm{p}=0.055$.

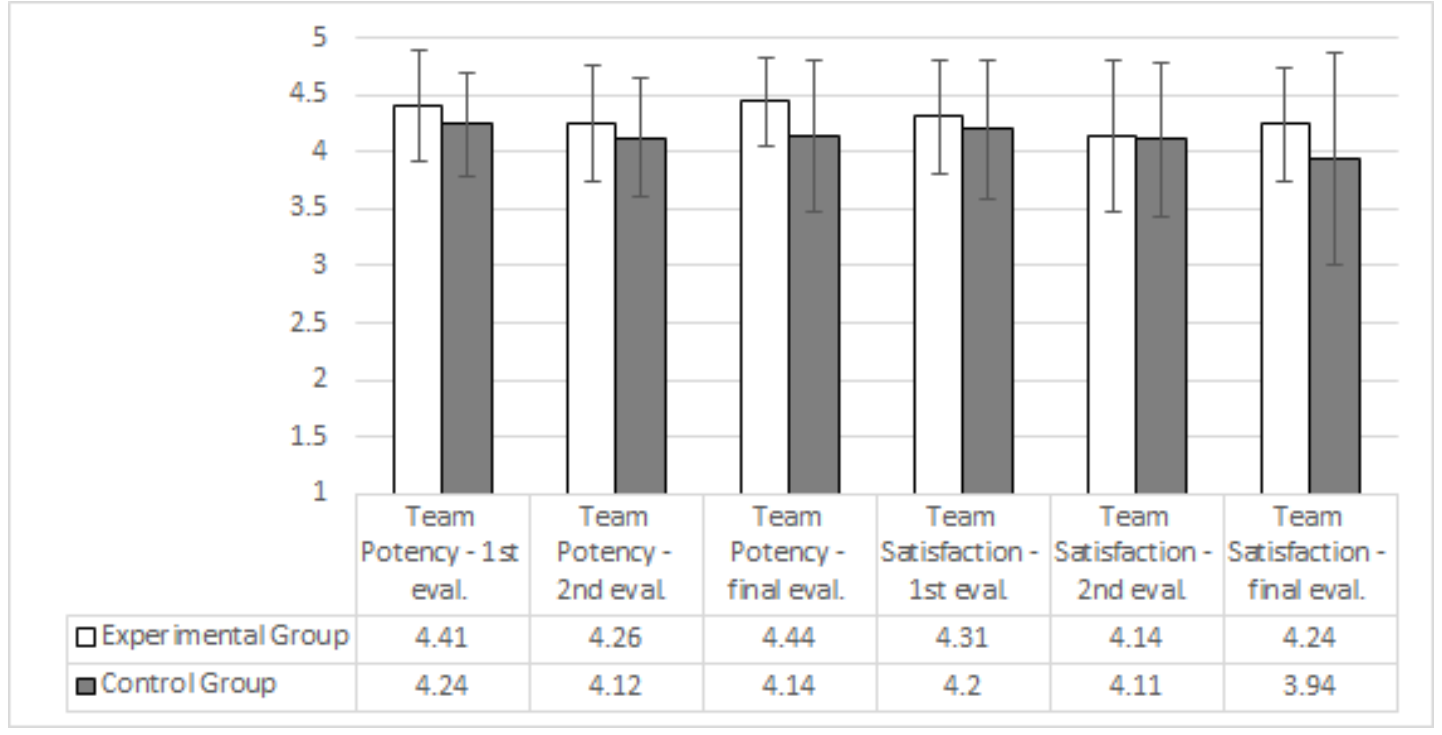

Figure 3. Mean values for team potency and satisfaction

\section{Conclusions and Future Work}

To summarize, the work presented in this paper aims to evaluate whether the intervention of cohering the first year engineering course with the Small Group Communication course has led to better team dynamics in the team projects, using the team CARE model. The team CARE model assessment tool which contains 81 Likert scale questions covering different aspects of the four dimensions of team skills: Communicate, Adapt, Relate, Educate, as well as team potency and team satisfaction was administered to the experimental and control groups three times throughout the semester. Through quantitative analysis of the data, it was found that overall the experimental group had higher mean values for the majority of the questions in all three evaluations. Statistically significant differences were found in results for questions related to healthy, fact-driven conflict (first evaluation), coordination, and contribution equity (both in final evaluation) between the two groups. This means that experimental group teams engaged in discussions about the pros and cons of different opinions or debated about different viewpoints more often than the teams in the control group did in the small design challenge. In the large design project, they communicated better with each other within the teams, integrated their individual work efforts into final team products more smoothly, and coordinated their activities with each other in a better way; and there was less tension in the experimental group teams due to lack of contributions from team members and less disagreement about task distribution, as well as other team logistic issues. The results also suggest that control group teams had less personal conflict in the small project. For the majority of the other questions, though the 
experimental group outperformed the control group, the differences were not found to be of statistical significance.

Areas of future work include removing anomalies in the data, e.g., when only one or two out of

four members completed the assessment, and incorporating qualitative research methods such as focus groups, interviews, and observations for a more thorough analysis.

\section{References}

[1] National Academy of Engineering. 2004. The Engineer of 2020: Visions of Engineering in the New Century. Washington, DC: The National Academies Press.

[2] ABET, "Criteria for Accrediting Engineering Programs, 2018 - 2019," ABET, 2018. [Online]. Available:https://www.abet.org/accreditation/accreditation-criteria/criteria-foraccrediting-engineering-programs-2018-2019/. [Accessed 30 Jan 2019].

[3] Bodnar, L. J., \& Lagoudas, M. Z., \& Hodge, J. Q., \& Smith, T. A., \& Orozco, J. A., \& Corso, J. G., \& Sanchez, C. R., \& Freise, J. K., \& Ringler, H., \& Cortes, I. (2012, June), Engaging Freshman in Team Based Engineering Projects Paper presented at 2012 ASEE Annual Conference \& Exposition, San Antonio, Texas. https://peer.asee.org/21288

[4] Gatchell, D. W., \& Ankenman, B., \& Hirsch, P. L., \& Goodman, A., \& Brown, K. (2014, June), Restructuring Teamwork Pedagogy in a First-Year Engineering Design Program: Lessons Learned and Future Plans Paper presented at 2014 ASEE Annual Conference \& Exposition, Indianapolis, Indiana. https://peer.asee.org/22981

[5] Porter, J., \& Wright, G., \& Morgan, J. (2005, June), Managing Senior Design Projects To Maximize Success: The Tat Team Paper presented at 2005 Annual Conference, Portland, Oregon. https://peer.asee.org/15336

[6] Ezzell, S., \& Gordy, P. (2004, June), Energizing Your Engineering Program Through Competitions And Team Based Projects Paper presented at 2004 Annual Conference, Salt Lake City, Utah. https://peer.asee.org/13973

[7] Lumsdaine, E., \& Loukus, J., \& Dreyer, J., \& Chenoweth, S., \& Lumsdaine, M. (2009, June), Forming And Managing Project Teams In A Large Capstone Design Course Paper presented at 2009 Annual Conference \& Exposition, Austin, Texas. https://peer.asee.org/4892 
[8] Harding, T. (2007, June), Benefits And Struggles Of Using Large Team Projects In Capstone Courses Paper presented at 2007 Annual Conference \& Exposition, Honolulu, Hawaii. https://peer.asee.org/3009

[9] Underwood, H. R., \& Pratt, D. G. (2014, June), Competitive Placement of Engineering Students on Multiyear Project Teams Paper presented at 2014 ASEE Annual Conference \& Exposition, Indianapolis, Indiana. https://peer.asee.org/20194

[10] Zhu, H. (2016, June), Implementing Open-ended Hands-on Design Projects throughout the Mechanical Engineering Curriculum Paper presented at 2016 ASEE Annual Conference \& Exposition, New Orleans, Louisiana. 10.18260/p.25596

[11] Larson, N. L., \& Hoffart, G., \& O'Neill, T., \& Eggermont, M., \& Rosehart, W. D., \& Brennan, B. (2015, June), Team CARE Model: Assessing Team Dynamics in First-year Engineering Student Teams Paper presented at 2015 ASEE Annual Conference \& Exposition, Seattle, Washington. 10.18260/p.24832

[12] Lingard, R. and Barkataki, S. (2011), Teaching Teamwork in Engineering and Computer Science, in Proc. 41th IEEE Frontiers in Education Conf. IEEE.

[13] Borrego, B., Karlin, J., McNair, L.D., and Beddoesc, K. (2013), Team Effectiveness Theory from Industrial and Organizational Psychology Applied to Engineering Student Project Teams: A Research Review, Journal of Engineering Education, vol. 102, no. 4., pp. 472-512.

[14] Wheelan, S. A. (Ed.). (2005). The Handbook of Group Research and Practice. Thousand Oaks, CA: Sage.

[15] Guzzo, R. A., \& Shea, G. P. (1992). Group Performance and Intergroup Relations in Organizations. In M. Dunnette \& L. Hough (Eds.), Handbook of Industrial and Organizational Psychology (2nd ed. vol. 3, pp. 269-313).). Palo Alto, CA: Consulting Psychologists Press.

[16] Mathieu, J. E., Heffner, S. T., Goodwin, G. F., Salas, E., \& Cannon-Bowers, A. J. (2000). The Influence of Shared Mental Models on Team Process and Performance. Journal of Applied Psychology, vol. 85, no. 2, pp. 273-283.

[17] Kozlowski, S. W. J., \& Ilgen, R. D. (2006). Enhancing the Effectiveness of Work Groups and Teams. Psychological Science in the Public Interest, vol. 7, no. 3, pp. 77-124.

[18] Sheppard, K., Dominick, P., \& Aronson, Z. (2004). Preparing Engineering Students for the New Business Paradigm of International Teamwork and Global Orientation. International 
Journal of Engineering Education, vol. 20, no. 3, pp. 475-483.

[19] Alexander, M. (1985). The Team Effectiveness Critique. In L. D. Goodstein \& J. W. Pfeiffer

(Eds.), The 1985 annual: Developing human resources (pp. 101-106). San Diego, CA: University Associates.

[20] Adams, S. G., Zafft, C. R., Molano, M. C., \& Rao, K. (2008). Development of a Protocol to Measure Team Behavior in Engineering Education. Journal of STEM Education: Innovations \& Research, vol. 9, no. 1/2, pp. 13-20.

[21] Hackman, J. (1987). The Design of Work Teams. In J. Lorsch (Ed.), Handbook of Organizational Behavior (pp. 315-342). Upper Saddle River, NJ: Prentice-Hall.

[22] Beyerlein, S., \& Davis, D., \& Thompson, P., \& Trevisan, M., \& Harrison, O. (2006, June), Assessment Framework For Capstone Design Courses Paper presented at 2006 Annual Conference \& Exposition, Chicago, Illinois. https://peer.asee.org/842

\section{[23] https://www.itpmetrics.com/}

\section{Appendix A. Team CARE Model Assessment Tool Questions}

Please report your agreement on each of the following statements regarding your team. (Strongly Disagree, Disagree, Neutral, Agree, Strongly Agree)

\section{Category I: Communicate}

Strategy Formulation:

1. We develop an overall strategy to guide our team activities.

2. We prepare contingency ('if-then') plans to deal with uncertain situations.

3. We know when to stick with a given working plan, and when to adopt a different one.

4. We periodically re-evaluate the quality of our working plans.

5. We specify the sequence in which work products should be accomplished.

Role Clarity:

1. We feel certain about how much authority we each have.

2. There are clear, planned goals and objectives for each of our roles.

3. We divide our time and efforts properly.

4. We know what our responsibilities are.

5 . We know exactly what is expected of each other. 


\section{Cooperative Conflict Management:}

1. Team members encourage a 'we are in it together' attitude as they negotiate their differences.

2. Team members seek a solution that will be good for all of us.

3. Team members treat conflict as a mutual problem to solve.

4. We work so that to the extent possible we all get what we really want.

5. Team members combine the best of positions to make an effective decision.

Category II: Adapt

Team Monitoring and Backup:

1. We inform team members if their work does not meet standards.

2. We seek to understand each other's strengths and weaknesses.

3. We support each other when needed.

4. We help a team member who is overwhelmed with tasks.

Emphasizing Goal Progression:

1. Regularly monitor how well we are meeting our team goals.

2. Use clearly defined metrics to assess our progress.

3. Seek feedback about how well we are meeting our goals.

4. Know whether we are on pace for meeting our goals.

5. Let team members know when we have accomplished our goals.

Coordination:

1. Our team communicates well with each other.

2. Our team smoothly integrates our work efforts.

3. Our team members coordinate our activities with one another.

4. Our team re-establish coordination when things go wrong.

Category III: Relate

Trust:

1. My team members show a great deal of integrity.

2. I can rely on those with whom I work in this group.

3. Overall, my team members are very trustworthy.

Healthy, Fact-Driven Conflict:

1. To what extent do your team members argue the pros and cons of different opinions?

2. How often do your team members discuss evidence for alternative viewpoints?

3. How frequently do your team members engage in debate about different opinions or ideas?

Lack of Personal Conflict: 
1. How much emotional conflict is there among your team members?

2. How much anger is there among your team members?

3. How much personal friction is there in the group during decisions?

4. How much are personality clashes between team members evident?

5. How much tension is there in the group during decisions?

Contribution Equity:

1. How often is there tension in your team caused by member(s) not performing as well as expected?

2. To what extent is there tension in your team caused by member(s) not completing their assignment(s) on time?

3. How much tension is there in your team caused by member(s) arriving late to team meetings?

4. How frequently do your team members disagree about the optimal amount of time to spend on different parts of teamwork?

5. How frequently do your team members disagree about the optimal amount of time to spend in meetings?

6. How often do your team members disagree about who should do what?

Category IV: Educate

Exploratory Learning:

1. Team members systematically search for new possibilities.

2. Team members offer new ideas and solutions to complicated problems (are inventive).

3. Team members experiment with new and creative ways for accomplishing work.

4. Team members evaluate diverse options.

5. Team members develop many new skills.

Exploitative Learning:

1. Team members recombine existing knowledge for accomplishing work.

2. In our team, we primarily perform routine activities.

3. Our team implements standardized methodologies and regular work practices.

4. Team members improve and refine their existing knowledge and expertise.

5. Team members mainly use their current knowledge and skills for performing their tasks.

Constructive Controversy:

1. Team members express their own views directly to each other.

2. Team members listen carefully to each other's opinions.

3. Team members try to understand each other's concerns.

4. Team members try to use each other's ideas.

5. Even when we disagree, we communicate respect for each other.

6. We work for decisions we can all accept. 
7. All views are listened to, even if they are in the minority.

8. We use our opposing views to understand the problem.

Team Potency and Satisfaction

Team Potency:

1. Our team has confidence in itself.

2. No task is too tough for our team.

3. Our team believes it can solve any problem it encounters.

4. Our team believes it can be very productive.

Team Satisfaction:

1. I like working with my team members.

2. Compared with other teams I have worked on, this team works well together.

3. I prefer working with this team rather than by myself.

4. I would not pursue an opportunity to leave this team and work on another.

5. I look forward to working with my team members in the future. 